\title{
ANTIOCHUS III AND HIS TITLE 'GREAT-KING.'
}

IT is not generally realized that to speak of Antiochus III-the Antiochus who makes a figure in Roman History-as Antiochus the Great is strictly speaking incorrect, although, as a popular form of speech, it goes back to the time of Polybius, ${ }^{1}$ and is even found on some monuments. ${ }^{2}$ Other monuments give us the form which is obviously the more correct, the official, form. The Seleucid kings had, it is well known, official surnames. We find

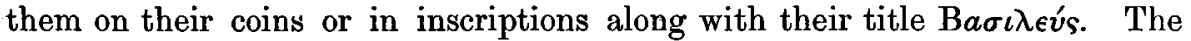
three elements of their designation have their regular order-title, personal

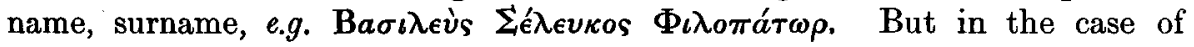
Antiochus III the inscriptions of most authority, which give his designation

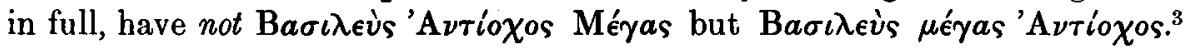
That is to say, Méras is not really a surname at all: but Antiochus III is distinguished by a modification of his title: he is not simply 'King' but 'Great-King.' The popular form is especially misleading to us who have the way of calling kings the Great to imply vaguely some sort of personal preeminence, as when we speak of Alfred the Great, Frederick the Great, \&c. 'The title 'Great-King' has quite a definite significance.

Long before, when the leading civilization of Asia was that on the Euphrates or Tigris, the paramount sovereign there used as one of his chief titles that of Great-King (šarru rabû),' and occasionally the title 'King of kings' (šar šarrâni) or 'Lord of kings.' These titles carried with them the definite connotation of holding the chief power in that group of lands which centred in Babylon, just as Imperator or Augustus in a later age meant the Emperor of Rome. And just as in the West the barbarian conqueror adopted the Roman tradition and became Imperator Augustus, ${ }^{6}$ so in the East in the sixth century B.c. the Persian dynasty which conquered the Babylonian Empire took over the two titles of 'Great-King' and ' King of kings.' 7 Among the Greeks before Alexander, as every one knows, $\dot{o} \beta a \sigma \iota \lambda \epsilon \dot{s} \varsigma$ ó $\mu$ ćyas

1 iv. $2,7$.

2 E.g. C.I.G. No. 4458.

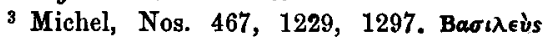
'Avrloxos Méryas, so far as I know, never occurs. Where the $\beta a \sigma i \lambda \epsilon$ 's is omitted, we find Ayrioxos Méras, as in C.I.G. No. 4458. This is natural, since something is wanted to distinguish him from other kings of the name, and his title being omitted, the distinctive part

H.S. VOL, XXII. of it is used in place of a surname.

4 E.g. Inscription of Sennacherib, Schrader, Keilinschrift. Bibliothek ii. p. 80.

5 Tiele, Babylonisch-assyrische Geschichte, p. 493.

${ }^{6}$ Bryce, Holy Roman Empire, Appendix, Note C.

7 Spiegel, Die altpersischen Keilinschriften. 
always meant the Achaemenian king. $\quad$ The other title, 'King of kings,' was also not unknown to the Greeks. A rescript of Darius Hystaspis to a certain

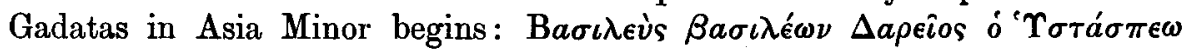
$\Gamma a \delta a ́ \tau a c ̧$

Now it is a remarkable thing that during the Macedonian supremacy these titles are in abeyance. No Seleucid, so far as I know, is styled ' King of kings' even in Babylonian documents. The ruler is plain King (šarru). ${ }^{10}$ The most fulsome document is that put up by the Babylonian priests for Antiochus I which begins: 'I am Antiochus, the Great-King, the Mighty King, the King of the armies, the King of Babylon, the King of the lands (šar mâtâti), the restorer of Isagil and Izida, the princely son of Seleucus, the Macedonian King, the King of Babylon.' 11 It will be noticed that even here, among the various titles, that of 'King of kings' does not appear. In Greek documents, which, of course, are better evidence for the usage of the court than those drawn up by Orientals, we also fail to find the Seleucid king

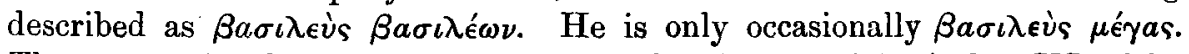
These exceptional cases are noteworthy. One is that of Antiochus III. The

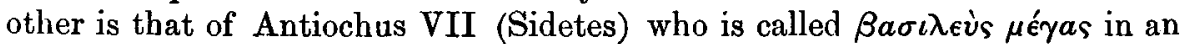
inscription of Delos. ${ }^{12}$ Antiochus III, we know, got his title from his restoration of the Empire in the East. When Antiochus VII mounted the throne (B.c. 138) Iran and Babylonia had been conquered by the Parthian. It was his great achievement to reconquer them for the last time for the house of

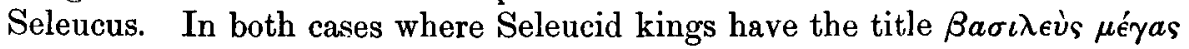
it is where there is a special reason for emphasizing the Eastern dominion. ${ }^{13}$

This is borne out by other instances of the use of the title outside the house of Seleucus.

(1) In the inscription put up in honour of Ptolemy III Euergetes

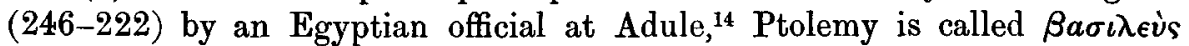
réryas. What was this Ptolemy's chief title to fame? His conquest of the East 'as far as Bactria.'

(2) The title is adopted by the Arsacid kings-according to Mr. Percy Gardner's classification, by the first king who established himself in Parthia (about 248); according to the more recent view of $\mathbf{M r}$. Wroth, ${ }^{15}$ by a king in the earlier part of the second century. In any case, it was the ambition of the Parthian kings to represent themselves as the successors of the Achaemenians, the paramount Kings of the Nearer East.

(3) The title is found on the coins of Eucratides (190-160), whose realm was Further Iran, but who could as legitimately represent himself as the

\footnotetext{
8 Hdt. i. 188 \&c.

9 Michel, Recueil d'Inscriptions Grecques. No. 32=Hicks and Hill, No. 20.

10 Strassmaier, Zeitschr. f. Assyr. viii (1893), p. 106 f., of. Sehrader, Sitzungsb. d. Berlin. Akad. 1890, p. 1331.

1 Keilinschrift. Bibliothek iii., p. 136.

12 Michel, No. 1158.
}

13 Cf. Justin xxxviii, 10, 6 (of Antiochus vii). 'Tribus prœlits victor cum Babyloniam occupasset, magnus haberi coepit,' where wo see the same popular perversion of the title as in the case of Antiochus III.

14 C.I.G. No. $5127=$ Michel No. 1239.

15 Numismatic Chronicle. Third Series, vol. $\mathrm{xx}(1900)$, p. $181 \mathrm{f}$. 
successor of the Achaemenians as the German ruler of the Middle Ages could represent himself as the successor of the Caesars.

(4) The rebel satrap Timarchus (about 162-160) calls himself $\beta a \sigma \iota \lambda e \grave{s}$

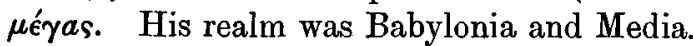

The other title, ' King of kings,' $\beta a \sigma \iota \lambda \epsilon \dot{s} \varsigma \beta a \sigma \iota \lambda \epsilon ́ \omega \nu$, although eschewed by the Greek kings, was revived in the East. It ultimately replaces that of $\beta a \sigma \iota \lambda \epsilon \dot{u} s \mu$ éfas upon the Parthian coins. ${ }^{16}$ It was adopted by Tigranes of Armenia, whose conquest of the Seleucid kingdom (in 83) gave him a claim to inherit the Seleucid pretensions to the Empire of the East. ${ }^{17}$

Of course, after this time the imperial style became fashionable at the Eastern courts and was affected by kings who could not possibly represent themselves as the paramount Kings of the East. Pharnaces II of Pontus (63-47) combines both the titles we have been considering and calls himself

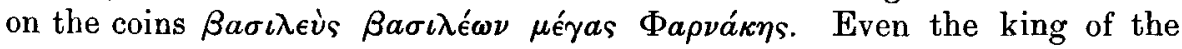

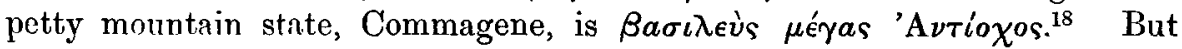
these kings had at any rate the excuse that they reckoned Achaemenian and Seleucid kings among their ancestors, ${ }^{19}$ and reigned over what had once been part of those ancestors' realm. There was less justification in the case of the degenerate Ptolemy (Ptolemy Auletes, 81-58), who appears by inscriptions to have been called on occasion $\beta a \sigma \iota \lambda \epsilon \dot{v} \varsigma \mu \epsilon^{\prime} \gamma a{ }^{20}{ }^{20}$ But to this improper use of the imperial titles we again find a parallel in the West-the use of the titles Imperator, Augustus, and Basileus (which then meant Eastern Roman Emperor) by the English kings in the tenth century. ${ }^{21}$

We also find persons writing without official authority applying the traditional Oriental titles to the Greek kings. The Pseudo-Aristeas calls Ptolemy II $\beta a \sigma \iota \lambda \epsilon \dot{\nu} \varsigma \mu^{\prime} \gamma_{a s}{ }^{22}$ In the Phoenician inscriptions put up by private individuals in Cyprus under Ptolemy II we find the King called, 'Lord of Kings' (adôn melakîm). ${ }^{23}$ But this naturally proves nothing for the usage of the court.

Why did Seleucids and Ptolemies adhere to the plain title of $\beta a \sigma \iota \lambda \epsilon u$ s? To understand this, we have again to note that $\beta a \sigma l \lambda \epsilon v^{\prime}$ had in their case a special implication. When Antigonus first called himself King in 306, there was in theory no division of the Macedonian realm. Antigonus assumed the title as being King of the Macedonians, the heir of Alexander. ${ }^{24}$ So in the case of his rivals, when they followed suit, it was to the Macedonian kingship that

16 Its first appearance in the Parthian series is on coins which were assigned by $\mathrm{Mr}$. Gardner to Mithridates I (174-136), but which Mr. Wroth gives to Mithridates II (123-88). It is found on coins of the Indian rajah Maues about 120.

17 The coins on which Tigranes uses it are those struck in Syria.

18 Inscription of Nimrûd Dagh, Michel, No. 735.

19 Cf. Justin xxxviii, 7, 1: Inscription of Nimrûd Dagh.

${ }^{20}$ Strack, Dynastie der Ptolemäer, Nos. 154 and 155 .

21 Freeman, History of the Norman Conquest, vol. $1^{3}$ p. $548 \mathrm{f}$.

$22 \S 29$. In other passages $\S 35$, $\$ 41$ the plain

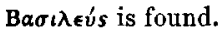

${ }^{23}$ C. I. Semit. Pt. i. Tom. i. p. 112.

24 Of course the general sense of $\beta \alpha \sigma i \lambda \epsilon \dot{s}$ continued common. But in the case of the great Macedonian houses (those of Antigonus, Seleucus, \&c.), it had in the first instance been adopted as implying succession to the Mace donian throne. 
they laid claim. Demetrius the son of Antigonus refused to recognize the royalty of the other kings. ${ }^{25}$ Of course, in practice, each king had ultimately to acquiesce in a certain territorial sphere, but $\beta a \sigma \imath \lambda \epsilon u$ s nevertheless meant

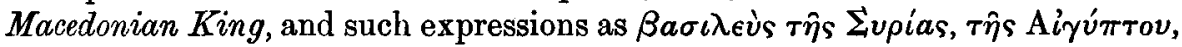
$\& c$. are merely convenient popular descriptions, never officially used. "The Empire of Alexander we have still, in spite of its divisions, to regard as a single whole. ... The divisions had followed each other in such quick succession, that they were unable to form stable territories with fixed frontiers and clearly marked characteristics. ... Each one of the new kings held himself entitled to increase his share according to his power and opportunity, or even to advance a claim to the whole.' ${ }^{26}$ Yet again, we find a parallel in the Roman Empire. In the Middle Ages, when there was an Eastern, as well as a Western, Emperor, each in theory regarded the other as a usurper, whilst in practice they might enter into friendly relations.

To be $\beta a \sigma \iota \lambda \epsilon$ śs therefore was to be a Macedonian, an Hellenic, king: to be $\beta a \sigma \iota \lambda \epsilon \dot{v} s \mu$ '́fas was to be an Oriental one, the successor of the Babylonians and Persians. The plain title was the prouder. Just so to-day King Edward sets his title of Britanniarum Rex before that of Indiae Imperator. ${ }^{27}$

E. R. Bevan.

${ }^{25}$ Plutarch, Dem. 25.

${ }_{26}$ Niese. Geschichte der gricch. u. maked. Staaten, ii. p. 123.

27 My thanks are due to Mr. G. F. Hill and
Mr. Wroth for their help in verifying the numismatic data, adduced in this article, and to Mr. R. C. Thompson for similar help in respect of the cuneiform inscriptions. 